breeding in the now deeper living space they would become genetically isolated from the parent form. A forced exploitation of tho deeper levels loading in this way to considerable spociation and adaptive radiation will have produced tho olaborate and stablo eco-systems now found in deop warm waters.

P. S. Dixon, H. T. Powoll and T. J. Hart discussod speciation in Rhodophyta, Fucus and Diatomacea, respectively. All threo were of the opinion that an unparalleled confusion existed in these groups because of a shortage of good taxonomists. It was made clear that more attention will have to be given to a study of the plant in life at all seasons before a study of speciation can be attompted.

C. F. A. Pantin, in sumrning up, considered that the papers had shown the noed for further resoarch into the nature of the physical environment, and in order to undorstand the significance of this for the individual species physiological study of the organisms in relation to their onvironment is also needed. The very constancy of the environments of the sea makes it easier for us to appreciate that the onvironment, which dirocts seloction, includes biological factors which, since they are ovolving all the timo, do not reach final equilibria. He likened these apparontly constant environments to dynamic equilibria in opren systems.

A grant towards the expenses of the symposium was made by the International Union of Biological Sciences.

\title{
RECENT ADVANCES IN CONSERVATION OF HISTORIC AND ARTISTIC WORKS
}

T THE first international conference on this subject was held at Rome during Soptember 25-29, 1961. The conferenco was organized by the International Instituto for Conservation of Historic and Artistic Works, and attempted in a very full programme to survey all aspects of conservation.

The importance of this conference to readers of Nature, who are more aware than most of the difficulties of communicating specialized information, was that topics ranged from the use of refined electronic techniques to a discussion of the esthetic principles of conservation. There were many who were lost in one or other of these fields, and some who suggosted that there ought to be separate sessions at future conferences. But it is likely that in ten or twenty years, as basic scientific knowledge becomes more widespread, whatever the refinements developed by that time, there will be more common ground in such a conference, not less.

It may not be generally realized thet many of the world's major museums have attached to them a conservation studio, and sometimes also a sciontific laboratory. Notable are tho National Galleries of London, Washington, Ottawa and New South Wales, the British Museum, the Victoria and Albert Museum, the Tate Gallery and the chief museums in Boston, Harvard University, Madras, Naples, New York, Prague and Zurich to mention only some. In some countries conservation activities are also centralized within an institute, such as the Istituto Centralo del Restauro (Rome), the Academy of Fine Art (Warsaw), the Courtauld Institute (London), the Doerner Institute (Munich), the Federal Institute for Protection of Cultural Monuments (Belgrade), the Intermuseum Laboratory (Ohio), the Laboratoire de Recherche Archéologique (Nancy), the Now York Conservation Center and the Smithsonian Institution Freer Gallery. 'The heads of all these departments and organizations were among the delegates at the Rome conference.

Tho Centro Internazionale di Studi per la Conservazione ed il Restauro dei Beni Culturali, more shortly known as the Rome Centre, and the Istituto di Patologia del Libro deserve special mention, for the director of the former, Dr. H. J. Plenderleith, took a very prominent part in the organization of the conference, and the laiter were hosts to the delegates, providing lecture rooms and other facilities. The head of the organizing committee was N. S. Brommelle. head of tho Victoria and Albert Museum Conservation Department and secretary-general of the International Institute for Consorvation of Historic and Artistic Work; the treasurer of the latter is S. Rees Jonos.

The qualifications of restorors and conservators vary greatly in different countries. Museum directors, trained most frequently in humanist disciplines, find it difficult even to-day to judge the value of the contributions from their technical departments. In his opening address, Dr. A. van Schendel, president of tho International Institute and director of the Rijksmuseum, Amstordam-a very modern director in his understanding of the rolo of conservatorsdirected attention to the hope of the Institute that conservation is becoming a recognized profossion with professional standards of its own to maintain. To this end, fellowship of the Institute is not an easily acquired distinction.

In all attempts to prolong the lives of precious museum objects, the most important study is that of the museum 'climate', to which the opening session was devoted. Air conditioning is by now well established in the major museums, so that the present emphasis in research is on the effects of lighting. L. S. Harrison (United States) described his use of photocells for controlling the light in a museum, and J. Lodowijks (Holland) dealt in general terms with the chemical theory of photolysis and photochemical degradation as it affects museum objects.

Travelling exhibits are becoming increasingly popular and raise problems of packaging, often for conveyance through climates of widely varying humidity and temperature. Dr. N. Stolow (National Gallery of Canada) described some tests on methods of insulation, and Dr. K. Toishi (Japan), who was not able to be present, contributed work on tho use of silica gel as a humidity stabilizer within the package. H. Wakefield described packaging mothods used by the Victoria and Albert Museum in its many travelling exhibitions.

There were five speakers in the session on physical and chemical methods of analysis. W. J. Young (Museum of Fine Arts, Boston) and Dr. E. T. Hall (Research Laboratory for Archæology, Oxford) 
described the use in the analysis of museum objects of X-ray diffraction, X-ray fluorescence, the electron beam microprobe (X-ray micro-analysis) and $\gamma$-ray spectrometry. Some impressive information has already been collected by these very expensive methods which will, however, never replace the cheaper method of chemical or wet micro-analysis. This subject was covered by R. J. Gettens (Freer Giallery of Art, Washington) and Miss J. Plesters (National Gallery, London), who spoke of plans for organizing the scattered information now available on the materials used in antiquity, particularly pigments. The contribution of Dr. S. Augusti (Capodimonte Museum, Naples) was a survey of all these methods.

The second day was the busiest of the week, covering in the morning fungicides and insecticides, in the afternoon application of seience to the cleaning of paintings and examination and treatment of metallic objects. There was also a tour of the museum and laboratories of the Istituto di Patologia del Libro. Dr. L. Santucci (Istituto di Patologia) gave a welldocumented account of the entry of science into the restoration of archival materials. Dr. P. Gallo and IDr. F. Gallo (Istituto di Patologia) spoke respectively on the toxicity hazards of insecticides and of the micro-organisms and insects which are on record as having attacked books and manuscripts. Next, two members of the Istituto Centrale del Restauro, Prof. A. Tonolo and Dr. C. Giacobini, showed slides of attack by moulds and bacterie on wall-paintings in damp surroundings, mentioning that good atmospheric conditions are more important for preservation than any amount of insecticides. The next speaker, Mme. F. Flieder (Bibliothèque Nationale, Paris), was unable to be present, and her work was summarized by Dr. A. E. Werner. This dealt first with a method for ensuring that documents re-inforced with cellulose acetate or textile fabric remained properly fungicidal; and secondly, the methods which she had found effective for preventing mould formation in documents and books, and for treating infected documents. W. Boustoad (Art Gallery of New South Wales) gave a vivid account of difficulties with mould growth in Australia.

Concerning scientific contributions to methods of cleaning pictures, Miss E. Jones (Fogg Art Museum, Harvard University) gave useful data on the properties of aged synthetic resin varnishes, while Dr. N. Stolow's paper, describing his work on the effect of solvents on linseed oil, provoked a lively discussion, since it touched on the fundamental operation of removing old varnish without affecting old oil film.

Concurrently, a discussion was held on the very large subject of conservation of metallic objects. R. $\boldsymbol{J}$. Gettens (Freer Gallery of Art, Washington) described some of the unusual mineral alteration products found on ancient metal objects, including one or two of his own discovery. A. France-Lanord (Musée Lorraine, Nancy) told how very large bronze objects could be successfully repaired by the use of glass fibre and adhesive. The speciel contribution of Drs. C. Panseri and M. Leoni (Istituto Sperimentale dei Metalli Leggeri) was on advanced sampling techniques for metallurgical examination, including metallographic polishing and electrolytic etching of tiny areas of metal, and extraction of tiny cylindrical samples by high-frequency electric dischargo and ultra-acoustical elastic vibration. R. Organ summarized the methods used in the British Museum Research Laboratory for the examination and treat- ment of bronze antiquities. In particular, he dealt with the effective trestment of bronze disease, that is to say, the removal of all traces of cuprous chloride. Lastly, Mme. A. R. Weill of Paris summarized the non-destructive methods available in the examination of metallic antiquities.

To complete the day, Dr. H. J. Plenderleith, director of the Rome Centre, gave the Forbes Prize Lecture, taking as his subject the international organization and conservation.

The next morning was devoted to demonstrations and lectures on Italian methods of fresco transfer. This is a subject on which Italian restorers are the acknowledged authorities, having had quite outstanding experience. Prof. P. Mora (Istituto Centrale) and Prof. L. Tintori (Uffizi, Florence) gave critical accounts of the methods they had used in this seemingly dangerous operation of transferring large frescoes from sites in churches, etc., where deterioration had occurred, to safer atmospheric conditions.

Methods for strengthening and consolidating fragile objects are as important to the excavator as to the museum curator. Dr. A. E. Werner (British Museum Laboratory) concentrated on the stabilizing of waterlogged wood, describing many methods, but favouring that using polyethylene glycol wax for impregnation. R. Organ (British Museum Laboratory) and also Dr. H. Jedrzejewska (Poland) were concerned with the eonsolidation of metal objects. Mr. Organ described some ingenious methods used with success in the British Museum Laboratory. Dr. Jedrzejewska advocated the use of paraffin wax in the treatment of bronzes, a method which produced a certain amount of disagreement from her British colleagues. Finally, Mrs. A. Rosenquist (Universitetets Oldsaksamling, Oslo) gave a general background to the use of adhesives.

Two very different contributions on the subject of glass conservation were each exceptional. Dr. R. H. Brill (Corning Museum of Glass, New York) illustrated the use of the electron-beam microprobe for work previously impossible - the analysis of tiny inclusions in ancient glass. R. Wihr (Rheinisches Landesmuseum, Trier, Germany) showed some beautiful examples of replica work done with transparent cold-setting polymers.

A big problem in picture conservation is the tendency for wood panels to crack and warp, often causing flaking of paint. Three speakers on Thursday morning described the methods used in their museums. These were Dr. C. Wolters (Doerner Institute, Munich), A. Lucas (National Gallery, London) and Prof. G. Urbani (Istituto Centrale). The fourth speaker, R. D. Buck (Intermuseum Laboratory, Ohio), who has specialized for many years on the treatment of wood panels, described a method for backing panels which served also to form an effective moisture barrier.

The situation with respect to the use of synthetic resins as picture varnishes was described by Dr. R. L. Feller (Mellon Institute, Pittsburg) and G. Thomson (National (rallery, London), who have both specialized. in this subject. Vital information on the long-term properties of synthetic resins, particularly as regards possible development of insolubility, is at last becoming available. The use of infra-red spectrophotometry following the chemical deterioration of picture varnishes was also described.

There is considerable controversy over the use of synthetics in the treatment and repair of textiles and tapestries. Contributions came from Dr. A. Geijer 
(Stockholm), read by H. Burnham (Royal Ontario Museum), Dr. J. E. Leene (Laboratory for Textile Technology, Delft), Miss L. Bellinger (Textile Museum, Washington) and E. R. Beccher (Victoria ond Albert Museum, London).

The final session was on the subject of the education and training of conservators and restorers, perhaps the most important of all since, in the absence of proper training, standards cannot be maintained. Speakers were: Prof. P. Rotondi, the now head of the Istituto Contrale del Restauro, Rome; S. Keck, the now director of the New York University Conservation Center; H. Ruhemann (London), Prof. B. Marconi (Academy of Fine Arts, Warsaw) and H. W. M. Hodges (Institute of Archæology, London). There was unfortunately very little time for discussion.

Insufficient time for discussion was in fact tho major complaint of the delegates and was foreseon by the organizers. Only a limited time was available, and a huge range of subjects had to be represented. Future conferences will deal with certain of these subjects separately.
(XARRY THOMSON

\section{ANIMAL COMMUNICATION AND LEARNING PROCESSES}

$\mathrm{T}$

HE eighth of a sories of symposia organized by the Zoological Society of London was held during November 8-9 jointly with the Association for the Study of Animal Behaviour. The first day was devoted to a discussion of "Evolutionary Aspects of Animal Communication", and the socond to a discussion of "Imprinting and Early Learning".

Dr. N. Tinbergen (Oxford) oponod the fixst day's procerdings with a eritical oxamination of mothods or, as he put it, with 'soul-searching' concorning the validity of evidence derived from the study of present communication patterns for the making of generalizations about their evolutionary history and taxonomic relevance in the absence of 'fossil' evidence. Often the assessment of sequences proves difficult, and it is frequently hard to pin-poirit the solection valuo of deviations from the norm. The question was discussed whother the manifest act of communica. tion or its underlying neuromuscular pattern is the substrate for solection.

In a paper on the "Snapping Movement of the Blue Heron" Dr. G. P. Buerends (Groningen) submitted that the 'snap display' of this bird did not, as had been thought, originate as a displacoment activity from fish-soizing or nost-building but was primarily caused by an interaction of tendencios to attack and oscape and is thus a typically ambivalont movemont. The wing display of tho junglo fowl during waltzing was doscribed by J. P. Kruijt (Groningen) as a compromise between simultaneously activated motor patterns.

Prof. D. S. Lehrman, Rutgers University, analysed the part played by endocrine responses to sensory stimulation from follow-members of a species and omphasized the great importance of hormonal stimulusresponse relationships in the communication of physiological states. In a paper on the evolutionary aspects of courtship songs in the estrildine finches, Dr. Fae Hall (London) demonstrated that the song of these birds has no proved territorial or hostilo function, but is primarily a r tualized sexual signal immediately preceding copulation. The various songs appear to bo species-specific and act as sexual isolating mechanisms. Dr. J. H. Crook (Cambridgo) showed how in plocerine weaver birds the various combinations of six basic behaviour patterns aro associatod with habitat and solitary or gregarious habit. Or. M. R. A. Chance (Birmingham) diseussed the significance of agonistic postures and devoloped a hypothesis that they serve as cut.off onabling aversive drives to wane and social intercourse to continue.

Vocal communication patterns in Rhosus monkoys were demonstrated by Dr. 'Thelma Rowell (Cambridge), who pointed out that a set number of noises with their various intermediates can be identified, but prove to be closely associated with certain postures and movements. They cax therofore not be studiod in isolation, but only in conjunction with tho activity of the animal as a whole. Facial oxpressions in primates were discussed by J. van Hoff (Utrecht), who dirocted attention to the fact that only the higher primates, the highor carnivores and the ungulates have developed an elaborate system of social signels concentratod in the facial region, and that this sooms to be correlatod with tho specializations of the sense of vision. Various compound oxprossions each result from balance of aggression and fear.

Tho second day of tho symposium openod with loctures by Dr. TR. $\Lambda$. Hinde (Cambridgo) and Dr. E. Fabricius (Stockholm), who, each in his own way, challongod the critoria set out originally by Konrad Loronz as distinctive for this kind of learning. Thus it was argued that tho absenco of reward, the existence of a critical period, the rupidity of the process, its irroversibility, its supra-individual significance, the particular absence of any innate releasing mochanism, the question of regulative or mosaic determination, and finally tho relationship between imprinting and soxual orientation to the foster paront have all beon conclusivoly challonged by observation and experimont. Dr. Hinde pointod out that, although imprinting is not a uniquo form of learning, it poses many problems with wide ramifications and provides a context in which thoy can be studied in dotail.

In a paper on early learning in Sepia, M. J. Wolls (Cambridgo) showed how newly hatched animals are dominated by innate mechanisms for attack of cortain food organisms, but how later on an ever-widening range of objects elicit attack. During the first month aftor hatching thore is very little evidence of learning, but by the middle of the second month, that is, procisely when the vertical lobe of the brain becomos fully developed, the animals loarn to deal with more varied proy.

Prof, F. V. Smith (Durham) discussed certain perceptual aspects of imprinting, and described three groups of experimonts in which the perceptual factors in initial approach, tho duration of responses and relative strength of stimuli, and the hypothesis of effort (E. H. Hess) wore examined. Dr. W. Sluckin (Loicester) discussod the relationship botween perceptual and associativo learning and pointed to some important difforences betweon them. The capacity for percoptual learning remains steady for some time, but declines with age, whereas associative learning improves with age for a long time.

I)r. E. A. Salzen (Liverpool) analysed the relationships between "Imprinting and F'ear". Ho suggested 